\title{
ELEMENTOS PARA A ESCUTA E ANÁLISE DO JOGO DA VOZ NO SIMBÓLICO
}

\author{
Pedro Souza ${ }^{1}$
}

\begin{abstract}
Resumo
Pretendo, neste artigo, mostrar de que maneira a voz pode ser abordada como objeto simbólico, ou seja, fenômeno constituído no limite de algum procedimento interpretativo aplicado a um preciso processo de subjetivação. Para tanto, escolhi me ocupar da entrevista que Elis Regina concedeu ao programa Ensaio, em 1973. Metodologicamente, presto atenção aos pontos de transição entre a fala e o canto cometidos pela entrevistada na relação com seu entrevistador. O objetivo da análise é explicitar o jogo da voz materializando sonoramente uma enunciação que acontece no limiar de certa ordem de discurso, ou seja, a que rege a formação da música popular brasileira e o sujeito que nela se constitui cantando.
\end{abstract}

Palavras-chave: Voz; Enunciação; Subjetivação; Discurso

\section{INTRODUÇÃO}

Meu interesse, no trabalho que exponho a seguir, é analisar o processo de constituição do sujeito cantante no campo da música popular brasileira (MPB). Para isso, a proposta delimita como objeto a ser analisado o evento de uma entrevista em que uma cantora narra a própria trajetória no campo da MPB. Dessa maneira, recorto aqui a histórica participação da cantora Elis Regina (1945-1982) no Programa Ensaio, em $1973^{2}$.

\footnotetext{
${ }^{1}$ Professor associado IV na Universidade Federal de Santa Catarina. Atua como pesquisador na área de Teoria e Análise Linguística e Análise de Discurso, com contribuições estendidas à Teoria da Literatura. Universidade Federal de Santa Catarina, Endereço: Centro de Comunicação e Expressão. Campus universitário, Trindade, CEP: 88010-970 - Florianopolis, SC - Brasil - Caixa-postal: 476, Telefone: (48) 3319581, Brasil E-mail: pedesou@gmail.com

2 Esta emissão foi chamada MPB Especial, quando transmitida pela TV Cultura de São Paulo, em 1973. Mas, continua hoje a ser apresentada pela mesma emissora de TV, como Ensaio, nome com que foi ao ar pela primeira vez na extinta TV Tupi de São Paulo, como criação de Fernando Faro.
} 
De partida, adianto que, colocando-me na perspectiva em que o telespectador recebe a emissão televisiva, ancoro o gesto da análise não tanto no conteúdo do que é dito a cada réplica do entrevistado, mas no fenômeno que distingue o Programa Ensaio de outros do gênero talk show. Dessa forma, o que destaco, como motivação analítica, é a distribuição das vozes - do entrevistador e do entrevistado - ao longo desse programa de televisão criado especificamente para exibir cantores e cantoras enquanto falam e cantam narrando a própria vida do artista.

No vídeo, ao assistir ao Programa Ensaio, o espectador só vê e escuta a voz do convidado que fala e canta dirigindo-se ao alocutário, cuja imagem nunca é exibida e cuja voz nunca é escutada. Aí reside, propriamente, o input da análise: o dado da voz exibida como instrumento que trabalha a subjetivação em sua singularidade. Emprego o termo singularidade para descrever o processo em que a voz do artista entrevistado ganha autonomia para escapar ao investimento da memória discursiva. Esta chega ao artista, enquadrado em primeiro plano na tela da TV, através da voz não sonorizada do entrevistador, a que interpela conduzindo o entrevistado a se expor no trânsito entre o falar e o cantar. O escape a que aludo, aplica-se pontualmente ao reconstruído da posição de discurso no campo da MPB. Configurada dessa maneira, a cena, abordada em sua natureza de evento de enunciação, induz a investigar o que se passa discursivamente no plano da genealogia do sujeito cantante. Isso se pode descrever seguindo o fio de atos enunciativos expostos ao jogo de inscrição ou do traçado de linhas de fuga, em algum ponto da memória sustentadora da história da música popular brasileira.

Daí decorre que o crucial, nesse acontecimento suportado por aparatos midiáticos de som, luz e imagem, tem a ver com a subjetividade que se dá contraditória e concomitantemente centrada em si mesma e incrustrada na história que torna possível sua emergência. Em termos mais precisos, impõe-se que a fala do sujeito seja tomada no ponto em que, fora de si, provém do que foi dito antes e alhures. Assim é que, capturado no olho de uma nascente discursiva, em certo tempo e espaço, o dizer, simbolicamente arrolado na análise, pode expor-se na sua derivada propriedade de produzir sentido e sujeito.

É importante pressupor que o dispositivo midiático da câmera, do som e da luz deve concorrer para que a voz do cantor ou da cantora esteja sempre no primeiro plano da cena enunciativa que se realiza em um estúdio de televisão. Desta maneira é que a presença do entrevistador pode, analiticamente, adquirir o estatuto da voz atuando como o ponto de estofo 
SOUZA, Pedro.

da memória discursiva. Na medida em que não é apreendida sonoramente na enunciação interlocutiva, a voz do inquiridor, que não se escuta, funciona no sentido de aludir a algo que fala antes, tal como se pensa a constituição do sentido e do sujeito em Análise de Discurso (ORLANDI, 2003). Os sentidos do falar e do cantar são presentificados no Programa Ensaio, independentemente do que sabem entrevistador e entrevistado, acerca do já-dito determinando o dizer no instante da entrevista. Em síntese, essa voz inaudível traz o ritmo aleatório e inacessível da memória discursiva ou do interdiscurso, regendo o transcorrer da emissão televisiva em que um cantante fala e canta narrando a si na esteira do processo discursivo que torna possível sua subjetivação predominantemente operada pela voz.

Em suma, é importante salientar que o que está colocado em primeiro plano, na análise a se desenvolver neste trabalho, é a constituição do sujeito que canta. Este deve ser focalizado a partir do modo, ao longo do Programa Ensaio, como a cantora entrevistada dispõe sua voz em um ato de enunciação que se realiza na fronteira entre o canto e a fala. Pontualmente, tomo a voz na forma com que soa midiatizada no aparato da linguagem televisiva. Nesse caso, é preciso levar em conta a natureza do significante que ancora o processo enunciativo e discursivo: som vocal e imagem em movimento. Nisto consiste a materialidade que sustenta a dimensão simbólica no interior do qual a voz é escutada, ou seja, interrogada e interpretada na sua potência de produzir subjetividades. Em termos precisamente analíticos, o caso aqui é de tomar o acontecimento da enunciação no instante em que esta se encontra em vias de se deixar inscrever em certa região do interdiscurso. Emprego o conceito de interdiscurso para aludir aqui aos múltiplos discursos que se confrontam entre si para produzir a história da música popular brasileira (MPB).

\section{A VOZ SURDA DA MEMÓRIA}

O programa abre com Elis Regina cantando uma das faixas do disco lançado meses antes da entrevista. Enquadrada em close-up, imagem em preto e branco, Elis está de olhos baixos. De repente começa a falar como que respondendo a alguém que o telespectador não ouve e nem vê. Essa voz permanecerá inaudível durante toda a gravação e posterior transmissão do programa. A fala assonante do entrevistador, pouco a pouco, indicará o domínio de memória de onde as enunciações vozeadas pela cantora entrevistada serão acionadas. Dessa maneira, a voz a quem cabe a função de fazer falar e cantar não ostenta o 
domínio da situação interlocutiva, o que coloca a cantora no centro da cena. Assim, a voz a quem Elis Regina se dirige, funciona como portadora da rede de discurso em que ela é levada a falar e cantar, mostrando de que maneira ela se constitui como cantora a cada ato vocal realizado ali e somente ali, no instante em que é tomada por uma câmera que invade seu rosto e escutada por um microfone inteiramente à disposição de sua voz.

Logo após emitir os versos da canção escolhida para abrir sua apresentação - Doente, Morena, composta por Gilberto Gil -, Elis passa do canto da última frase melódica - e quando canto deixo a imaginação voar -, imediatamente à fala: "eu conheci o Gil em 1966, 65, talvez fim de 1965. Prossegue lembrando as circunstâncias em que foi levada a ouvir e escolher as primeiras criações musicais de Gilberto Gil. Fala do contato entre ela e o compositor como um bom e bem sucedido encontro. Arremata o depoimento desse encontro cantando Ladeira da preguiça.

Após o silêncio que se interpõe entre a cantora e seu interlocutor, o canto dá lugar à fala em que depõe sobre suas origens como indivíduo dotado de nome próprio e filiação - eu nasci em Porto Alegre, em 1945, no dia 17 de março, num domingo. Este é o momento, na entrevista, em que a artista narra por si mesma a trajetória entre o antes e o agora do tornar-se cantora. Em outras edições da série Ensaio, o padrão do programa é abrir com o cantor, apresentando-se no ponto em que cessa de cantar a música de abertura. Isso leva a supor que a adoção deste roteiro, especificamente para a edição em foco, aparece como estratégia de memória discursiva que, fincada na transição entre o falar e o cantar, apaga o tempo já dado e fixa, no ato de enunciar, o presente de sua constituição como cantora. No final desta passagem, Elis Regina relembra sua infância e os primeiros instantes em que, no contexto familiar, foi descoberta e se descobriu desejando cantar. É pertinente destacar o trecho em que ela alude ao momento em que já não cantava mais para obedecer a um chamado, mas para fazer da própria voz o lugar da relação consigo mesma como cantora.

Quando foi pra eu dar um presente para eles ótimo, eu fui lá, cantei e as pessoas badalavam, fizeram almoço. Aí quando eu comecei a gostar que eu comecei a querer dar 0 presente para mim, aí quiseram cortar porque não podia, não ficava bem, afinal cantora de rádio, aquelas coisas... Mas aí eu não tinha mais jeito. É que nem gente que começa a beber e não pode parar. Pra mim é cantar e coçar é só começar. 
SOUZA, Pedro.

Mas, ainda que se guiando pela força vocal, Elis não cessa de percorrer trajetos que a colocam na contramão das ordens discursivas que a obrigam a calar sua voz. De modo geral, o que está no alvo da crítica são regimes de escuta e constituição da voz cantante como objeto mercadológico.

A Continental precisava de uma cantora que fizesse frente a Cely Campelo, que na Odeon estava acabando com o baile. Mas eu, de antemão, já acho que este negócio de lançar alguém pra combater alguém, uma pobreza total absoluta, sempre achei. E eu não queria ser a sombra de quem quer que fosse, eu queria ser eu, fazer minhas coisas. E, a parte isto, o repertório, que é um nome maravilhoso, não era assim dos mais maravilhosos de você ouvir e rolar na sarjeta de paixão, aí ficou tudo esquisito. Mas tinha contrato, tinha que fazer, aquelas coisas, sabe como é.

Este é o ponto da entrevista em que o modo de enunciação se detém na fala e, diferente do que ocorreu antes, não dá passagem ao canto, modalidade enunciativa marcadora da memória do enunciador enquanto está em vias de se fazer como sujeito que canta. Ao rechaçar a qualidade do repertório de seu primeiro disco, Elis emenda como que respondendo a uma pergunta que vem do interlocutor que não se ouve: a primeira música eu me lembro mas não vou dizer, porque você vai pedir pra eu cantar e eu não vou cantar [...].

Como significa este gesto de recusa a cantar? É preciso atentar aqui para estrutura sequencial determinada pelo roteiro do programa: a cada episódio rememorado pela cantora, deve se seguir uma canção executada na continuidade da entrevista. Neste ponto, deveria ocorrer a transição da fala ao canto. Esta alternância é, conforme venho expondo, marca da linguagem da emissão televisiva adotada para o Programa Ensaio. Dessa maneira, garante-se o ritmo e a harmonia cuja propriedade é de indicar o movimento enunciativo do entrevistado enquanto se deixa atravessar pela memória que o interpela. A cada momento em que transita da fala ao canto, a cantora convidada aponta para si, subjetivando-se pela voz. Mas a voz, modulada no instante da conversa entre a entrevistada e o entrevistador, só vem como acontecimento em vias de se inscrever em dada região do interdiscurso da história da música popular brasileira. Refiro-me à rede de formulações, entremeio as quais a voz inaudível do entrevistador interpela a cantora, com falas que configuram, na cadeia das enunciações ali ocorrentes, a construção de certo domínio de memória. Assim, quando Elis Regina interrompe a passagem do ato de falar ao ato de cantar, em determinado trecho no curso de suas réplicas, a recusa a cantar determinada canção deve valer como uma indicação interdiscursiva de que o 
lugar de onde ela exibe sua voz não coincide com aquele em que cantou a melodia que, agora, se nega a entoar.

Note-se que o ato enunciativo de recusa - você vai pedir pra eu cantar e eu não vou cantar - mostra o quanto o vestígio de uma interdiscursividade afeta o discurso sobre si e a voz que a cantora quer fazer valer, ali, enquanto está sendo entrevistada. Tem-se a posição do sujeito que se dá pelo apagamento do fato de que há outros sentidos a embalar os processos de subjetivação da cantora ao longo da história da MPB. Em outros termos, é dizer que a memória do canto que constitui o sujeito que canta se produz pelo esquecimento enunciativo (ORLANDI, 1999) do que se passou antes do tempo em que ora fala e canta.

Dessa forma, as cenas de não atendimento ao pedido de entoar determinada canção nada mais indicam senão o traço da função enunciativa fundamental, que se define pelo espectro de variação de posições enunciativas a que se articula a voz, discursivamente, capturada no intervalo entre o falar e o cantar. Aludo aqui ao processo de subjetivação que, para ter lugar, é preciso que outro se apague na cadeia da memória evocada na voz inaudível do entrevistador. A função enunciativa fundamental corresponde ao que resta da rede de sentidos como efeito do esquecimento. Tal é o exemplo do processo subjetivo em que Elis Regina se situa no intervalo entre três épocas de sua história de cantora: o começo no final dos anos de 1950; os novos percursos em 1963, tempo da identificação com o movimento da moderna música brasileira, e o presente em 1973, quando fala e canta no Programa Ensaio. Em termos do aqui e agora de sua enunciação, importa dizer-se no lugar discursivo desde quando se viu reconhecida como aquela que, ao cantar, mostra ter algo a dizer.

Examinemos o trecho em que o modo de a cantora responder à pergunta inaudível não só alude às canções que a fizeram reconhecida pelo público e pela crítica, mas opera um deslocamento no interior do qual aparece o andamento descontínuo de sua subjetivação.

Há controvérsias. Umas pessoas dizem que é Meninos das laranjas, outras dizem que é Arrastão. Mas eu tenho a impressão que a primeira música que eu cantei e que as pessoas se tocaram assim que eu tinha alguma coisa pra dizer, foi Preciso aprender a ser só. Foi num show no Little Club.

No final deste depoimento, põe-se, logo em seguida, a cantar a canção Preciso aprender a ser só. Certamente, o gesto não serve apenas para lembrar, mas para fazer ouvir em voz e tempo outros - a cantora que se torna no aqui e agora do atual ato de enunciação 
SOUZA, Pedro.

cantada. Quando termina de emitir o último verso, olha sorrindo para o entrevistador perguntando e respondendo: Quando que eu cantei isso? Devia ser 64, fim de 64. A câmera a mostra de perfil, em segundos de silêncio, mirando um ponto situado além de quem está diante dela. Após a breve pausa, diz sem ser interpelada:

\section{[...] eu fiz um disco na Philips. Entende? Quer dizer foi a primeira gravadora que acreditou nas coisas que eu também acreditava. E eles me convidaram pra fazer o disco e eu fiz com as músicas que eu gostava.}

Diz isso e olha fixamente para o interlocutor. Sorri como se replicasse em silêncio algum comentário sonoramente dirigido apenas a ela. Faz outra pausa e retruca negando-se a atender ao pedido de cantar uma outra canção: [...] mas eu acho que o pessoal não sabe tocar... Mas eu acho que não precisava né. Arrastão é um negócio que ficou tão na cabeça das pessoas que não precisa, assim, tah lembrando a eles.

Prossegue falando e relembrando a primeira vez que cantou Upa neguinho. Recorda que solicitou ao conjunto Som Três um arranjo para esta composição de Edu Lobo. Na ocasião, Cesar Camargo Mariano fazia parte do grupo e ri quando menciona a cara que ele fazia no momento. Vimos antes que, nesta emissão do Programa Ensaio, ela não quis cantar Arrastão, mas, depois de evocar a lembrança do encontro com Som Três e César Camargo Mariano, passou, sem hesitar, da fala à entoação de Upa neguinho. Eis aí um assentimento seguido de uma recusa. São atitudes que se sobrepõem na mesma cadeia de enunciação. Daí vem que o canto de Upa neguinho torna audível a voz do tempo presente, a que soa pelo esquecimento da sonoridade vocal que, em outro tempo, o mesmo corpo operou em Arrastão.

Vê-se que a periodização que orienta a narração de si da cantora não é casual, nem se baseia em uma natural sucessão cronológica. Os pontos de referência para essa periodização, que ancora a fala, já estão ditos na memória que, através da interpelação surda do entrevistador, suscita em Elis Regina o dizer de como se tornou o sujeito que ora se apresenta no Programa Ensaio. O essencial é o esquecer a ser trabalhado na periodização escolhida. Não se trata do fato como objeto de esquecimento, mas do próprio ato de esquecer que é inerente à produção do sentido e à subjetivação.

Assim, o acontecimento do sujeito que canta em Elis Regina, enquanto está sendo entrevistada em Ensaio, vem por uma distância irredutível entre o já dito, sem o que o sentido não se dá, e o a dizer, pelo qual o sentido e o sujeito emergem como outro. Dessa maneira, é 
que o gesto de falar e cantar deve funcionar no tempo em que dura a entrevista, tempo este estabelecido pela memória que significa o presente da subjetivação da cantora. Assim, ressalto as condições enunciativas em que Elis Regina se deixa inquirir, exposta ao dispositivo de uma entrevista televisiva. Esse modo de exposição de si é baliza da memória discursiva com que a cantora se constitui singularmente como acontecimento subjetivo na história da música popular brasileira.

É como se o Programa Ensaio em questão, mobilizasse seu dispositivo não para contar, em primeira pessoa, na linha contínua da memória, a história de uma cantora. Nesses termos, Elis Regina deve ser tomada em um presente absolutamente embreado, a fim de que, a remissão à voz que ressoa em tempo e espaço alhures, venha como o impossível do modo com que tende a se subjetivar no ato da enunciação que deriva e é derivada pela entrevista. Este ponto de vista conduz a indicar o modo como significa o fato de Elis se negar a atender ao pedido de cantar Arrastão. Trata-se de apagar o acontecimento da voz que, indiferente ao regime vigente de contenção vocal e gestual, cantou explosivamente a mesma música no $1^{\circ}$ Festival da Música Popular Brasileira da TV Excelsior, em 1965. No aqui e agora do Programa Ensaio, é imperativo que o sujeito que canta em Elis Regina, instantaneamente, resulte do hibridismo entre minimalismo vocal e intensidade emotiva. Outra subjetividade cantante $^{3}$ torna-se igualmente possível mediante modulações vocais outras entoando Upa neguinho.

Comparado com outras emissões, este programa traz a característica singular de interpor digressões provocadas pela voz - surda e fora do campo visual do telespectador - do entrevistador, interrompendo alguma sequência temática pré-estabelecida. Isso faz com que o que vem depois do canto possa ser a fala induzida por um tema qualquer. Aí, a fala faz-se como ponto de continuidade de outra que a conduz no extra campo de sua imagem e espaço de onde, só a ela endereçada, soa a voz do entrevistador. É o caso do depoimento sobre seus desencontros com colegas já falecidos. Justamente por dizer algo do movimento de subjetividade na transição entre falar e cantar, destaco os trechos dos testemunhos da cantora que se aplicam tanto aos cantores Ciro Monteiro ${ }^{4}$ quanto a Agostinho dos Santos ${ }^{5}$.

\footnotetext{
${ }^{3}$ Anos depois deste programa, 1979, Upa neguinho, mediante arranjo, produção e direção de Cesar Camargo Mariano levou a voz de Elis Regina soar no mesmo espaço enunciativo dos grandes jazzistas quando se apresentou no 13 Festival de Jazz de Montreux

${ }_{4}^{4}$ Cantor e compositor carioca (1913-1973). cf. Dicionário Cravo Albin da Música Popular Brasileira http://www.dicionariompb.com.br/cyro-monteiro/biografia
} 
SOUZA, Pedro.

A propósito de Ciro Monteiro, lembra ter sido ele o primeiro com quem cantou na TVRio. Depois de uma pausa silenciosa, atentando para o pedido inaudível do entrevistador, avisa não saber se vai conseguir cantar até o fim. E canta Formosa, de Ciro Monteiro: formosa não faz assim, carinho não é ruim.... Quando a voz fica quase engolida pela emoção, corta. Depois de uma breve pausa, afirma quase repentinamente: neste caso específico eu não fiquei encabulada. Não é propriamente encabulada; é ressabiada porque do Ciro jamais partiria qualquer coisa pra uma pessoa que não fosse bondade.

O telespectador pode não atinar do que de fato se trata na referência da expressão adverbial 'neste caso'. Mas isso não importa, pois, ainda que intuitivamente, quem está de fora da conversa entre a cantora e seu interlocutor, percebe que, na diferença explicitada entre proferir encabulada ou ressabiada, pontua-se a distância entre duas maneiras de dizer e, consequentemente, entre discursividades díspares. Mais adiante, retomo a esta ocorrência para, oportunamente, aplicá-la ao conceito de alusão como um fato metaenunciativo. Para o momento, cabe logo apontar como esta forma de colocar palavras em distância concorre, nos termos da memória de si que a cantora procede em sua fala, para marcar a posição de onde registra para a posteridade o sentido dos encontros pessoais ocorridos no contexto de sua carreira artística. Na trilha deste modo de dizer o sentimento pelos colegas, Elis abre espaço para aludir a afetos nunca revelados: [...] é muito triste as pessoas só saberem que a gente gosta delas depois que elas se foram. (Pausa) É. Com Agostinho foi assim. Imediatamente começa a cantar a canção Estrada do sol, composição de Dolores Duran, gravada por Agostinho dos Santos.

Nesse ponto, a transição da fala ao canto, remete ao que escapa da captura do acontecimento a que se refere o diálogo entre a cantora e o entrevistador. Depois de cantar Estrada do sol, Elis Regina prossegue afirmando não estar segura de ter conseguido se fazer entender pelo entrevistador - Eu não sei se você me entendeu. Talvez eu não tenha me feito entender direito. Fala então da presença de Agostinho dos Santos ao redor:

Eu tô sabendo que ele tah aí, entende? Quer dizer ele tah por aí. E, evidentemente, ele deve estar muito precisado de coisas boas. E é o mínimo que eu posso fazer. Talvez rezar (grifo meu) fosse uma coisa boa. Mas eu acho que cantando as coisas dele, lembrando a pessoa dele para as pessoas que um dia esqueceram que ele existia e que ele

\footnotetext{
${ }^{5}$ Cantor e compositor paulista (1932-1973). cf. Dicionário Cravo Albin da Música Popular Brasileira. http://www.dicionariompb.com.br/agostinho-dos-santos
} 
estava precisando delas, talvez ele se sinta melhor. Por isso é que eu resolvi cantar (grifo meu) a música dele e eu vou cantar sempre.

Da mesma forma com que se contrapõe o dizer de encabulada ao dizer de ressabiada, aqui a diferença entre rezar e cantar ocorre, na fala da cantora, ao modo de mais um caso de metaenunciação, que põe em evidência a distância entre dois atos enunciativos inseridos, cada um, em diferentes e irredutíveis discursividades. Nos termos da alusão, tal como concebida por Jacqueline Authier-Revuz (1995, p. 12)

\footnotetext{
Tomada nesse sentido estrito, a alusão conserva alguma coisa do seu sentido original, "jogo de palavras" (ainda ligado a sua origem, "ludus"): nas palavras que enuncia, o enunciador joga com a possibilidade de fazer ressoar, não outras palavras da língua como no trocadilho ou no equívoco, mas palavras de outros dizeres, suscitando, através da sua voz, a música de uma outra voz.
}

Seguindo este raciocínio, digo que Elis Regina comete, neste ponto, com maior intensidade, um jogo com palavras de outros dizeres, insinuando, mediante sua voz, a melodia de outra voz. Trata-se de dizer, sinalizando o sujeito em que se torna ao cantar a música da voz de Agostinho dos Santos: neste exato instante da entrevista, já não se escuta mais seu canto como puras dêixis da voz apontando para si, sendo cantora enquanto canta, mas o sujeito dispondo da sua para fazer passar a voz de outro: Por isso é que eu resolvi cantar a música dele e eu vou cantar sempre.

Dessa forma, é que se pode escutar diferentemente a passagem da fala ao canto como maneira de dizer, ou seja, interrogando, através da enunciação cantada, o sentido de encontros não mais possíveis de se fazerem dentro e fora do diálogo em curso. O instante deste gesto vocal inscreve, na trilha da memória discursiva que dá forma à história da música popular brasileira, o acontecimento de um processo mais aberto de subjetivação. Refiro-me, precisamente, às subjetividades quaisquer, que a voz opera mediante a propriedade de dizer cantando o que não pode dizer falando. Dito de outro modo, a voz passa do falar ao cantar como que liberando o dizer que não pode ser realizado pela fala. Cabe aqui aplicar a distinção proposta por Alain Boillat (2007, p. 23 a 30 e 335 a 346.): entre voz-atração e voz-narração. No ato de cantar, a voz é atuada como atração quando se trata de exibir o sujeito fazendo-se como cantor, ao passo que, enquanto narração, a voz aponta para o sujeito constituindo-se 
SOUZA, Pedro.

como narrador. Em outros termos, é como dizer que, na linha de força da memória, algo da exterioridade do discurso alude pela voz a diferentes possibilidades de captura de sentido.

Nessa passagem, a introdução do tema de seus difíceis relacionamentos funciona como que uma vaguidão especifica ${ }^{6}$ que suspende o foco temático do roteiro da entrevista, isto é, a exibição da cantora no tempo em que modifica a maneira com que canta. Assim, conduzir a cantora a falar de sua relação com determinados compositores é o fio condutor que detém a andamento da conversa entre Elis Regina e o invisível apresentador de Ensaio. Na sequência, depois de falar de Edu Lobo, Elis testemunha ainda seus encontros com Baden Power, Chico Buarque de Holanda, Milton Nascimento e Nelson Cavaquinho. Mas o retorno a esses nomes próprios, como figuras de uma trajetória linear, só aparece no transcorrer dos depoimentos da cantora para marcar o presente ampliado de sua enunciação como ponto de referência de uma mudança.

Na transição para a segunda parte, com a apresentação de seus músicos, caracterizados pelas pessoas que são - inseparáveis de seus talentos -, vem enfim a figura do sujeito cantante cuja história no presente de sua narrativa é indissociável de sua vida de $\operatorname{artista}^{7}$. Assim, assume um valor de testemunho inscrito na sua existência de e como cantora, o que ela diz quando passa a cantar 20 anos blue, de Sueli Costa e Vitor Martins. Eu gosto desta música, porque tem muita coisa a ver comigo, as coisas da letra. Eu também tenho mais de vinte muros, também tenho mais de vinte anos, aliás quase trinta. E e aquilo ali, aquilo ali, é muito parecido comigo. Não se trata de dissociar do sujeito que canta uma forma outra de subjetividade. O trabalho da voz dentro da melodia vem para manifestar a vida e a subjetivação a ela atrelada como obra de arte.

Na sequência do programa, vem à memória da cantora o período em que apresentava o programa $O$ fino da bossa, na TV Record. Imediatamente fala de como recebeu Chico Buarque de Holanda em sua casa. No que diz respeito ao trabalho da memória discursiva, esta é uma passagem a ser destacada na entrevista. A cantora desfia, neste preciso instante, a lembrança do que precisa ser esquecido a fim de que a luz se abra sobre o agora do sujeito que

\footnotetext{
${ }^{6}$ Alusão à crônica de Millôr Fernandes "Vaguidão Especifica ‘. In FERNANDES, Millôr. Trinta anos de mim mesmo. São Paulo, Círculo do Livro, 1976, p.77.

${ }^{7}$ Importante destacar o conceito implícito na expressão "vida de artista". Isso se refere ao que Michel Foucault levanta na história da arte, nos fins do século XVIII, inicio do século XIX, ou seja, a ideia de que a vida do artista não deve ser distanciada de sua obra: "Não somente a vida do artista deve ser suficientemente regular para que ele possa criar sua obra , mas sua vida deve ser, de certo modo, uma manifestação da própria arte em sua verdade" (FOUCAULT, 2011, p. 164)
} 
quer se enunciar sendo enquanto canta. Nesse sentido, a interpretação de Atrás da porta, composição feita para ela, por Chico Buarque, acontece como que um clímax no transcorrer da conversa entre ela e seu entrevistador. A imagem que a câmera capta e esquadrinha diz da transição entre o cantar e o falar. Aqui ganha especial destaque o momento em que a cantora emite os últimos acordes e versos da canção. Ela baixa levemente a cabeça, mantendo-se nesta postura, por átimos de segundos, muito significativos. A atitude exibida aqui contém o sentido que a voz acaba de sonorizar guiada pela letra e melodia. O rosto da cantora é focado por uma linguagem de câmera que, em certa ordem simbólica, abrigando os discursos do entrevistador e da entrevistada, significa o instante de quem acorda de um transe. Dirigindo-se diretamente para o seu interlocutor, ela diz: "é uma dor que não cabe no mundo". $\mathrm{O}$ telespectador ouve a voz em vias de transportar-se do canto à fala. Ressalta-se, mediante o aparato da linguagem televisiva, o intervalo dentro do qual acontece a passagem para uma outra instância de discurso. A maneira de dizer opera a alusão instantânea a não coincidência entre o sujeito que agora fala e o que acabou de cantar, e deixa entre-escutar a dor que ela só pode enunciar cantando.

Elis Regina, na edição do Programa Ensaio que ora focalizo, prossegue falando e cantando constante e inteiramente ancorada em seu aqui e agora. Mas o projeto discursivo sustentado por uma sucessão de enunciações embreadas no presente histórico de sua vida de cantora, fica ainda mais explicitado quando é levada a introduzir o tema de sua mais recente gravação.

Pra mim não foi susto nenhum esse disco porque eu toh me acompanhando há um ano. Então eu não estranhei minha modificação. [...]. Eu mudei! Não foi o meu disco que mudou! Foi minha cabeça que mudou, foi minha vida que mudou, foram os meus nervos que descansaram! Entende? O meu travesseiro que é muito mais aconchegante, a minha casa que é muito mais gostosa, a minha vida que é muito melhor...

Trata-se agora do ponto da entrevista em que a evocação da crítica apoia-se na alusão a um outro dizer: Pra mim não foi susto nenhum... Eu não estranhei. Formulado com palavras alheias, o enunciado contendo o pronome "eu" serve para aludir à transformação que a cantora vem realizando em seu cantar. Elis Regina, falando em primeira pessoa, assume do que é capaz agora, que a voz está lapidada graças às transformações a que se deixou submeter, ao entregar-se à direção musical do pianista César Camargo Mariano. Nenhuma das palavras 
SOUZA, Pedro.

a seguir poderia ser enunciada pela cantora a não ser pelo que suscita de preconstruído na contemporaneidade do discurso que provê de sentido o que ela diz.

As pessoas não vão entender que o César, um pianista chegado ao brejeiro, que sempre tenha feito coisas leves e digestiveis [...], de repente tenha resolvido ficar tão intelectualizado... Não se tocaram que a coisa mais intelectualizada do disco é justamente a gravação de que É com esse que eu vou. Certo? Porque era um samba de carnaval em cima do qual foi feito todo um trabalho de modificação de harmonia e de outras coisas. Então o que as pessoas acham que é a coisa mais simples, muito ao contrário, é a coisa mais difícil.

O que mais pode haver nesta alusão ao discurso outro, senão a abertura para a remissão a si e ao ato cometido pela própria voz? Nesse ponto, o que se representa como não evidente ou não transparente mediante a indicação da não-coincidência entre o dizer de ' $a$ coisa mais simples' e o de 'a coisa mais difícil”" acaba produzindo um ato de enunciação que se desdobra sobre si mesmo, tornando opaca sua pretensa referência. Não é que a cantora, ao se distanciar do discurso pertinente à crítica, envolva seu depoimento em puro narcisismo. $\mathrm{O}$ caso é que, nesse processo em que a fala só faz as palavras dobrarem-se sobre si mesma, o que resta a dizer e mostrar é presença materializada em corpo e voz. É a presentificação do sujeito que canta que, sub-repticiamente, incide sobre o vazio das palavras alheias. Eis o instante em que, glosando a maneira outra de dizer pertencente à crítica, a cantora alude ao seu próprio canto, impondo-se como objeto que se confunde com a enunciação que a ele se remete: Há pessoas até que dizem que tem músicas ali que não me merecem. Eu fico muito honrada com isso. Fico felicíssima de acharem que eu tô tão alta assim que uma música não me mereça. Em síntese, as palavras do outro são mencionadas como maneiras de dizer imbricadamente remissíveis à própria cantora enquanto comete o ato de falar e de cantar.

Observa-se, para empregar os termos de Authier-Revuz (Op. Cit., p. 12), um certo deslocamento subjetivo e discursivo, em que a cantora deixa-se invadir por algo que é da ordem "do "surgimento" enunciativo do outro da linguagem ". Aqui a passagem da fala ao canto é crucial. Porque se a conotação com que empregou as palavras da crítica não ultrapassou sua função meramente referencial (a maneira de dizer tornou opaca a referência ao disco e à crítica), o ato de cantar o samba de Gilberto Gil, Meio de campo, muito além de apenas brincar com a linguagem dos outros, no domínio do futebol - a perfeição é uma meta defendida pelo goleiro que joga na seleção... -, Elis faz da glosa futebolística o outro 
da linguagem, posição em que monta seu lugar auto ostensivo de enunciação. Esse modo de enunciar permite fazer-se ver e escutar simplesmente através do ritmo e sonoridade vocal, em vias de convertê-la em outra cantora na transição dos anos 60 para os anos 70. Pode-se dizer que aparece aí, dramatizado, o clímax da narrativa da vida de uma cantora. Tudo o que se pode apreender, analiticamente, de sua subjetividade cantante vem obrigatoriamente do que, sob os auspícios da ordem discursiva que a interpela, venha e continua falando e cantando ao longo da emissão televisiva.

Com isso reitero a forma como a enunciação, em sua modalidade reflexiva, funciona como a presença vocal operando o instante em que o sujeito torna-se cantante enquanto canta, isto é, nem antes, nem depois de abrir a voz. No caso da aparição de Elis Regina, na emissão televisiva em foco, trata-se sempre de mostrar, pela análise que até então procedo, o deslocamento, de uma para outra posição, no ato de cantar. É preciso dizer que tal deslocamento obedece ao já dito da história da cantora, a saber, à discursividade em que se aloja a escrita da história da música popular brasileira. Chego, enfim, ao que pretendi com este trabalho, isto é, à sugestão de alguns elementos procedimentais para a análise de um processo de subjetivação que toma como objeto simbólico a voz, está tomada na e pela escuta de sentidos possíveis em formação em dada região interdiscursiva.

\section{CONCLUSÃO}

Tomado como espaço enunciativo, o Programa Ensaio comporta um dispositivo cuja historicidade está ligada à abordagem da voz que nele se fabrica como objeto simbólico. Sob esta perspectiva, adotando o Programa Ensaio como plataforma de análise, quis destacar o que é olhado e escutado enquanto acontecimento da constituição de um sujeito que canta. Nesse sentido, Ensaio converte-se no documento de como o próprio cantor narra a memória

pela qual se vê transformado em sujeito que canta. É preciso, para tanto, que os elementos heterogêneos do dispositivo da linguagem televisiva devem ser colocados em relação, de modo a vê-los e ouvi-los funcionar, para além de sua materialidade especifica. Assim a luz, a imagem, os sons funcionam mais que simples produto técnico, na medida em que formam uma rede cujo ponto de aplicação é mostrar a voz falando e cantando. Esse movimento em rede leva ao telespectador não o sujeito cantante, mas o modo como ele se constitui, através 
SOUZA, Pedro.

da narrativa de si mesmo, conectada à historicidade exterior da música popular brasileira. Eis como a voz torna-se o objeto simbólico, tomada em um dispositivo que expõe o trabalho de subjetivação que nela se opera.

Tratou-se, nesses termos, de adentrar uma esfera subjetiva através do fio condutor da voz assentada em um corpo, mas nunca de modo direto, pois há sempre o discurso a mediar esta relação: tanto na fala de outro, quanto na fala de si, causada pela fala que o outro comete, ante a emissão de uma voz. A necessária orquestração discursiva é de forte relevância metodológica no sentido de que é pelas remissões de um dizer ao outro que se pode trazer à tona, a voz tornada objeto simbólico, já que, na enunciação, é atravessada por efeitos de sentido que sustentam nela a aparição do sujeito que canta e fala.

Abordada da maneira com que compõe a estrutura enunciativa singularmente pertinente ao Programa Ensaio, a voz torna-se então objeto simbólico exposto tanto ao locutor que a emite quanto ao outro, invisível, que a escuta. O simbólico aqui diz respeito ao modo como sucessivas articulações vocais remetem ao processo de formação de uma certa subjetividade. É preciso que a escuta esteja sintonizada não apenas nas ondas sonoras do falar ou do cantar, mas nos entremeios interpretáveis desses dois atos enunciativos, mutuamente, irredutíveis.

O mote da análise realizada neste trabalho incidiu, portanto, sobre o processo discursivo que permite escutar, a cada programa, uma voz cantante enquanto acontece no sujeito que canta. Por isso mesmo, o procedimento analítico deve sempre ser pautado pelo posicionamento das séries de enunciação aqui delimitadas no quadro do discurso, sobre a música popular brasileira. É, em relação a essa discursividade orquestrada por críticos, especialistas, estudiosos e historiadores da canção popular que cada emissão do Programa Ensaio deve ser escutada. Só assim pode-se isolar a voz que se apresenta em sucessivos atos enunciativos, encadeados de uma emissão a outro como objeto do discurso.

ELEMENTS FOR LISTENING AND ANALYSIS OF VOICE SET IN SYMBOLIC

\begin{abstract}
I intend in this paper show how the voice can become symbolic object, ie, a phenomenon consisting in the limit of some interpretive procedure applied to a precise process of subjectivation. To do so, I look for the interview with Elis Regina in emission tv, 1973,
\end{abstract}


named Programa Ensaio. Methodologically, I pay attention to the points of transition between speech and singing committed by the singer in connection with your interviewer. The objective of the analysis is to explain the game's voice loudly materializing an utterance that happens on the threshold of a certain order of discourse, ie, this one that determine the formation of brazilian popular music and the subject who sings.

Keywords: Voice; Enunciation; Subjectivity; Discourse

ELEMENTOS PARA ESCUCHAR Y ANÁLISIS DE VOZ EN JUEGO SIMBÓLICO

\section{Resumen}

Tengo la intención en este trabajo de mostrar de qué modo la voz se puede tratar como un objeto simbólico, es decir, un fenómeno que se constituye en el límite de algún procedimiento interpretativo aplicado a un proceso preciso de subjetivación. Para ello, opté por focalizar la entrevista que Elis Regina dio en el Programa Ensaio en 1973. Metodologicamente presto atención a los puntos de transición entre el habla y el canto cometido por el demandado en relación con su entrevistador. El objetivo del análisis es explicitar el juego de la voz al materializar sonoramente un enunciado que tiene lugar en el umbral de un cierto orden del discurso, es decir, que rige la formación de la música popular brasileña y el sujeto que en ella se constituye cantando.

Palabras clave: Voz; Enunciación; Subjetivación; Discurso

\section{REFERÊNCIAS}

AUTHIER-REVUZ, J.. Nos riscos da alusão. Tradução de Ana Vaz e Dóris Arruda Carneiro da Cunha. Disponível em: http://www.revistainvestigacoes.com.br/Volumes/Vol.20.N.2 2007 ARTIGOSWEB/JacquelineAuthierRevuz_NOS-RISCOS-DA-ALUSAO_Vol20-N2 Art01.pdf. Acesso em: 22 Mar. 2015.

BOILLAT, A. Du bonimenteur à la voix-over, Voix-attraction et voix-narration au cinéma. Lausanne, Éditions Antipodes, coll. « Médias et histoire », 2007. 
SOUZA, Pedro.

FERNANDES, Millôr. Trinta anos de mim mesmo. São Paulo, Círculo do Livro, 1976

FOUCAULT, Michel. “Aula de 26 de janeiro de 1983”. O Governo de Si e dos Outros. Curso no Collège de France (1982-1983). Tradução de Eduardo Brandão. São Paulo: Editora Martins Fontes, 2010.

FOUCAULT, Michel. “Aula de 29 de fevereiro de 1984”. A coragem da verdade. O Governo de si e dos outros. Trad. Eduardo Brandão. São Paulo: Editora Martins Fontes, 2011.

ORLANDI, Eni. Análise do discurso: princípios e procedimentos. Campinas: Pontes, 1999.

ORLANDI, Eni. Texto e Discurso, formulação e circulação dos sentidos. Campinas, SP: Ed. Pontes, 2002.

PÊCHEUX, Michel. Discurso: estrutura ou acontecimento? Trad. Eni Orlandi, Campinas: Pontes, 1990.

Data de recebimento: $18 / 02 / 2015$

Data de aceite: $23 / 03 / 2015$ 